\title{
DINIZ, Debora. 2012. Carta de uma orientadora: o primeiro projeto de pesquisa. Brasília: Letras Livres. 108 pp.
}

Talita Viana O livro de Debora Diniz é uma carta destinada às estudantes que se encontram $(U n B)$ na eminência da escrita de seu primeiro trabalho acadêmico. Trata-se não dos procedimentos metodológicos para a realização de uma pesquisa, mas de orientações e provocações para a experiência da criação e da autoria na vida acadêmica. Definida pela autora como um texto que busca guiar o encontro entre orientadora e orientanda - na obra denominadas /eitora-ouvidora e aprendiz de escritora - a obra fala do ritual de orientação, do encontro intelectual e profissional que se dá nessa parceria em busca da primeira criação textual da aprendiz de escritora.

A carta surge da trajetória de Debora Diniz como orientadora de pesquisas acadêmicas. A autora registrava os questionamentos trazidos por suas orientandas e os respondia em formato de mensagens. Essas mensagens, lidas tanto por suas orientandas quanto pelas orientandas de colegas da autora, respondiam a questões e angústias comuns àquelas que se encontravam frente ao desafio de virem a ser autoras de seu primeiro texto acadêmico. A partir daí a carta foi se desenhando e antecipa, portanto, os principais questionamentos respondidos por uma orientadora.

O texto apresenta as "regras do jogo" da pesquisa e produção acadêmica à aprendiz de escritora, mas, mais do que isso, conclama à reflexão sobre os sentidos e motivações dessa produção. Debora Diniz defende a produção criativa e comprometida com as realidades sociais - e suas transformações -, bem como a escolha por leituras e referenciais teóricos capazes de gerar deslocamentos nas leitoras (e futuras autoras).

A carta se divide em seções construídas em torno de encontros, todos conectados ao encontro que se dá na relação de orientação. Explicada as origens da carta na primeira seção (intitulada Uma carta), Antes do primeiro encontro trata da orientação sobre a escolha de uma orientadora. A posição da autora é a de que essa escolha, bem como a do tema da pesquisa a ser realizada, pertence à aprendiz de escritora. Chama então a atenção para a necessária redução desse tema, no intuito de deixá-lo o mais específico possível, e aponta alguns passos que facilitam essa etapa. 
Definida a orientação, $O$ primeiro encontro é o momento em que a aprendiz de escritora apresentará seus temas de interesse - pessoal ou político -, e seu desejo - de ordem privada. Segundo a autora, as motivações devem ser resumidas em títulos funcionais e problemas de pesquisa (objetivo geral e pergunta), com o máximo de especificidade possível.

O encontro com a pesquisa desenvolve mais detidamente as noções de título funcional, problema de pesquisa e palavras-chave, unidades básicas de um projeto de pesquisa. É explicitado o que deve estar contido em cada uma dessas unidades básicas, incluindo a quantidade de palavras bem como suas funções. Outro ponto abordado nessa seção e merecedor de destaque é o tremor na produção acadêmica, sensação que acena para a prudência e que deve ser uma constante companhia pela trajetória acadêmica. É chamada a atenção para a exposição pública que é a escrita, assim como para a "prudência criativa" que deve ser desenvolvida pela aprendiz de escritora. Esse tremor, contudo, não deve ser confundido com o temor - este, um inibidor da "liberdade de pensar e escrever" (DINIZ, 2012: 38).

O encontro com o tempo orienta a jovem pesquisadora na organização do tempo para o desenvolvimento do projeto de pesquisa. É sugerida a elaboração de um cronograma que inclui a pesquisa bibliográfica ou campo, leitura, escrita e revisão, etapas fundamentais da pesquisa e produção acadêmica. A autora, para quem a pesquisa é um ofício cumulativo e permanente, acredita no "treino intelectual para uso do tempo" (:48), desenvolvido com maior eficácia com o autoconhecimento e o disciplinamento. A escolha dos locais para o desenvolvimento das atividades da produção intelectual é também destacada.

$O$ encontro com o texto tem como eixo principal a atividade de leitura. Debora Diniz defende a escolha de leituras capazes de gerar deslocamentos: “Os deslocamentos nos inquietam, afugentam nossas certezas temporárias, mas nos movem rumo ao desconhecido de onde nascerá a criação genuína. É do deslocamento que nascerá sua voz de autora" (:56). Defende ainda a leitura criativa. Além disso, são sugeridos procedimentos facilitadores da organização da leitura, como o uso de programa de bibliografias e a confecção de um mapa de autores.

$O$ encontro com a escrita fecha a sessão de encontros presentes na carta. Inicia-se com a sentença da autora de que "não vale sofrer para escrever" (:63). O ofício de escritura do trabalho acadêmico é apresentado como uma experiência de descobertas e superações. Diniz adverte sobre o plágio e sugere rodadas de leitura dos textos produzidos pela aprendiz de escritora, conclamando-a à reflexão sobre a importância da submissão das suas produções a críticas. Provoca sua leitora - e futura autora de um texto acadêmico - com relação às motivações para a escrita contando, em um relato pessoal, que para ela a motivação para a escrita é de ordem existencial. Destaca ainda que escrever é arriscar-se, uma vez que se expõem publicamente ideias e argumentos e que, quando publicados, os textos ganham rumos próprios, independentes de suas autoras - além do fato de serem para sempre! Diniz defende o poder transformador da produção intelectual e convoca a aprendiz ao questionamento do sentido de sua proposta de projeto de pesquisa. É aqui também que a escolha feminista da autora se faz mais explícita e onde ela explica sua defesa da escrita no feminismo universal. Em um dos desfechos desse derradeiro encontro a leitora-ouvidora revela à aprendiz de escritora que agora, conhecidas todas as regras do jogo, é chegado o momento de violá-las. 
Encerrada a carta e as sessões construídas em torno dos encontros, leitora-ouvidora e aprendiz de escritora estão agora prontas para um encontro genuíno. O livro contém ainda uma sessão denominada $E$ o futuro?, onde a autora reflete sobre as possíveis impressões, no futuro, dessa primeira produção acadêmica. Sugere, no entanto, que não se sofra com essas impressões. Esse primeiro trabalho sempre acompanhará a aprendiz de escritora como o primeiro de sua trajetória. Contudo, Diniz alerta para a responsabilidade sobre o que se cria. Uma espécie de post scriptum traz um exemplo de mapa de literatura e uma proposta de cronograma para a organização do tempo, das etapas e dos produtos da pesquisa que terá início.

O livro de Debora Diniz apresenta, assim, elementos e regras da produção acadêmica, como definição do objeto de pesquisa, organização do tempo e autoria, sem perder de vista o caráter questionador e transformador das realidades sociais dessas produções. O pensamento livre e criativo é defendido, convocando as futuras autoras de textos acadêmicos a não apenas reproduzirem autoras de sua admiração. Motivações políticas na escolha dos temas de pesquisa, assim como produções comprometidas são valorizadas sem, contudo, colocar em segundo plano o rigor da pesquisa acadêmica.

Nesse sentido, o livro de Debora Diniz fornece alguns princípios fundamentais àquelas diante do primeiro projeto de pesquisa que, talvez por ter sido escrito a partir dos questionamentos de suas orientandas, consiga ser tão bem sucedido - e pioneiro - na proposta e abordar temas sobre os quais há uma carência na produção acadêmica. 